\title{
Global issue, developed country bias: the Paris climate conference as covered by daily print news organizations in 13 nations
}

\author{
Sonya Gurwitt ${ }^{1}$ (D) $\cdot$ Kari Malkki $^{1} \cdot$ Mili Mitra $^{1}$
}

Received: 20 September 2016 / Accepted: 4 June 2017 / Published online: 5 July 2017

(C) The Author(s) 2017. This article is an open access publication

\begin{abstract}
To understand how media portrayed the pivotal 2015 UNFCCC Conference of the Parties (COP21) in Paris, we assessed 2580 articles that appeared during the 2 weeks of the conference in the online versions of the two or three leading print newspapers in four developed countries, six emerging economies, and three developing countries: the USA, France, UK, Australia, India, China, South Africa, Brazil, Bolivia, Nigeria, United Arab Emirates, Indonesia, and Bangladesh. Categorization by key topics revealed that much of the coverage left readers with little understanding of many of the issues discussed at COP21, and in particular, those of high priority to developing nations. For example, there was little coverage of adaptation to climate impacts and far higher coverage of emissions reductions (mitigation). Print stories largely were updates on the talks, or focused on activists, the actions of world leaders at the conference, and the environmental effects of climate change. Furthermore, articles under-reported key issues for poorer nations such as equity, human rights, and the effects on human populations. Online coverage by print news organizations was heavily skewed towards the developed world, with little discussion of the most vulnerable countries or the issues that are important to them. These trends highlight the bias of coverage to developed nation perspectives and the persistence of journalistic norms that seek to emphasize drama, novelty, and balance in news coverage.
\end{abstract}

Authorship in alphabetical order with equal contribution from all authors.

Mili Mitra

mili_mitra@brown.edu

Sonya Gurwitt

sonya_gurwitt@alumni.brown.edu

Kari Malkki

kari_malkki@alumni.brown.edu 


\section{Introduction}

In November and December 2015, representatives and leaders from 196 countries arrived in Paris, France for the 2015 United Nations Framework Convention on Climate Change (UNFCCC) 21st Conference of the Parties (COP21). COP21 brought together a large number of politicians, journalists, scientists, academics, and civil society members from around the globe. The resulting Paris Agreement has been lauded as a turning point for the future of international climate policy. ${ }^{1}$ Numerous world leaders proclaimed the Paris Agreement to be "historic" and "unprecedented," setting a goal to limit temperature rise to $2{ }^{\circ} \mathrm{C}$ through increasingly ambitious emissions reduction targets.

At each UNFCCC conference since the first one in the first conference in 1995, nations have convened to review the implementation of the convention and build a fully binding climate agreement. The decisions made at these COPs have a lasting impact: They help determine how climate policy, both national and global, evolves and how financial resources to mitigate or adapt to climate change are distributed. These summits have also garnered considerable media and public attention. As Liu et al. (2011) conclude, "High-profile international events in the climate change field had very significant attention-grabbing power for both the media and congressional agendas. As expected, the news media tended to respond to international events instantaneously." (Liu et al. 2011, p. 415) Thus, COPs provide insight into broader trends in coverage of climate change and are a valuable opportunity for international comparison.

The media in turn has played a fundamental role in informing and updating the public about the climate ever since anthropogenic climate change emerged as a major global issue. Studies have shown that the mass media has been a primary source of climate news for the public (e.g., Brulle et al. 2012; Nelkin 1995; Wilson 2000a), journalists (Wilson 2000b), and policymakers alike (Sundblad et al. 2009).

Acknowledging the importance of the media in relation to climate change, many studies have explored media coverage of climate change in the USA (Antilla 2005; Antilla 2010; Gelbspan 2004; McComas and Shanahan 1999; Nissani 1999; Trumbo 1996; Zehr 2000; Boykoff 2008a). Others have looked at countries such as the UK (Boykoff 2008b; Doulton and Brown 2009; Gavin and Marshall 2011; Carvalho and Burgess 2005), Australia (McManus 2000; Henderson-Sellers 1998), Japan (Sampei and Aoyagi-Usui 2009), and Canada (Einsiedel 1992; Young and Dugas 2011). A few have analyzed climate change coverage from a cross-national perspective, notably Antilla (2010), Boykoff and Rajan (2007), O’Neill et al. (2015), Schmidt et al. (2013), and Brüggemann and Engesser (2017).

There appear to be several common trends that characterize much of climate change coverage in developed countries. Boykoff and Boykoff (2007) found that climate coverage was firmly entrenched in journalistic norms such as dramatization, personalization, and

\footnotetext{
${ }^{1}$ In articles that appeared near the end of COP21 such as "Obama hails Paris climate change agreement as a 'turning point for the world"" (The Telegraph, 12/13/2015); and "World Bank president celebrates "game changer' Paris talks" (The Guardian, 12/13/2015).

${ }^{2}$ Many articles cited Obama, Ban Ki-moon, and other notable public figures making these statements-for instance, in The New York Times ("Nations Approve Landmark Climate Accord in Paris"), Folha de São Paulo ("Acordo de Paris não é perfeito, mas é chance de salvar o planeta, diz Obama"—Translation: "Paris agreement is not perfect, but is a chance to save the planet, says Obama"), and The Guardian ("Political will for Paris climate deal 'unprecedented"').
} 
novelty. The Boykoffs specifically identify the journalistic norm of balance as an issue in framing climate change news; they assert that this balance leads to the inclusion of views from a handful of climate skeptics, skewing the coverage (Boykoff and Boykoff 2004). Coverage also tends to highlight the scientific uncertainty around climate science (Antilla 2005; Zehr 2000), particularly in the USA. Nissani (1999) argued that coverage in major US newspapers suffered from both superficial news stories and pro-corporate bias, while Antilla (2010) found that US journalists are especially cautious of making overstated projections that might lead to undue action, resulting in a "false negative" error. These issues are more prevalent in the USA than in Europe (Nelkin 1995).

A smaller body of research has investigated media coverage of climate change in developing countries and emerging economies. Shanahan (2009) looked at the unique barriers that journalists in non-industrialized countries face when covering climate change. He found that they were hindered by a lack of local research and experts, disagreements with editors, and insufficient resources (p. 146). Other studies focused on India (Billett 2010), China (Tolan 2007), Brazil (Fioravanti and Painter 2011), and South Africa (Tagbo 2010). These studies point to an increase in climate change coverage in these particular countries and with few inclusions of contrarian viewpoints. However, such media outlets either emphasize the riskresponsibility gap (Boykoff 2010) or repeat information from foreign sources (Tolan 2007; Shanahan 2009).

Recognizing the importance of COPs for the international climate agenda and as a focal point for climate change coverage, several studies have examined media coverage of individual COPS (McManus 2000; Painter 2010; Gavin and Marshall 2011; Boykoff 2012; Kunelius and Eide 2012). Of these, some studies have explored media coverage of individual developed countries: Australian newspaper coverage of COP4 in Buenos Aires (McManus 2000), skepticism in UK television and web coverage of COP15 in Copenhagen (Gavin and Marshall 2011), and discussion of economic impacts and opportunities of climate change and China's role in the negotiations in US newspaper and television coverage of COP16 in Cancun (Boykoff 2012). Additional research has taken a cross-national approach; Kunelius and Eide (2012) compared newspaper coverage of COP13 (Bali) and COP15 (Copenhagen) in multiple countries (13 and 19, respectively), finding that national government voices were the most quoted in global coverage, but there was also a strong international bias in summit reporting. Painter (2010) looked at newspaper coverage of COP15 (Copenhagen) in 12 countries and found that science was infrequently mentioned; even when it was, only a small percentage of quotes came from scientists, with journalists choosing to quote politicians instead.

Recent research has also explored the factors involved in story production at the COPs. Luck et al. (2016) examined the relationships between journalists and environmental nongovernmental organizations and found that a "camp feeling" at these summits creates "coproduction networks" that facilitate the sharing of information and expertise. Similarly, Wozniak et al. (2016) found that visual framing that favors NGOs is most prevalent in said media coverage. However, the researchers also found that there was a strong "statist orientation" (p. 1) in the mainstream news in terms of sourcing textual messages. This falls in line with Gans' (2004) analysis showing that "known" sources dominate the news (p. 9), due to the unavoidable push factors (such as pressure from key sources and editors) that influence journalists.

Finally, a select number of studies have looked at how climate change coverage varies over time. Several papers explored these trends through the lens of Anthony Downs' issue-attention 
cycle (1972), arguing that media attention performs an agenda-setting function (McComas and Shanahan 1999; Trumbo 1996). Schmidt et al. (2013) took this a step further in their investigation of media attention on climate change in 27 different countries between 1996 and 2010. The researchers found that climate coverage peaks during "focusing events" such as the release of the film The Inconvenient Truth and the announcement of the IPCC Fourth Assessment Reports. Of these focusing events, some of the largest peaks occurred during COPs, particularly COP15 in Copenhagen (Schmidt et al. 2013, p.20).

Consistent with the findings in Schmidt et al. (2013), COP21 in Paris in 2015 elicited another spike in media coverage of climate change (Luedecke et al. 2016). Little academic literature has, however, examined media coverage of COP21 or the breakdown by topic of the overall coverage. We particularly wanted to examine how coverage varied across the developed and developing world and what aspects of the multifaceted conference were actually covered: Which stories were emphasized and which were overlooked?

To do so, we analyzed themes in global media coverage of the COP2 1 during the 2 weeks of the conference by evaluating the nature and subject matter of over 2500 articles from the daily newspapers of 13 countries - three developing countries, four developed countries, and six emerging economies - in order to answer our questions as to how the conference, and climate change generally, were portrayed by the mainstream media across the global hierarchy.

We found that across all subject areas, many articles focused on hard news stories about the conference - statements from delegations or ministers at the conference, announcements of breaking news about the text or negotiations, or climate events happening around the world. Overall, news organizations across the globe demonstrated a consistent focus on developed country figures and policy priorities, to the detriment of issues more important to developing countries.

\section{Methods}

We selected 13 countries for this study: USA, France, UK, India, China, South Africa, Brazil, Bolivia, Nigeria, UAE, Indonesia, Bangladesh, and Australia (Appendix 1). Countries were chosen to reflect a wide range of geographic locations and levels of economic development. We chose countries that we judged to be major emitters and significant players at COP21 (such as China, India, and the USA), those especially vulnerable to the effects of climate change, and countries with different types of media and political systems. Our choices were constrained somewhat by the strength of each country's media, access to legitimate online newspaper source archives, and our translation capacities, which included French, Portuguese, Spanish, and English.

For each country, we selected two to three national, daily newspapers. ${ }^{3}$ While we recognize that the popularity of print news has declined in favor of other types of news delivery such as television or internet-only publications (Newman et al. 2016, p. 10), we chose to use the online versions of print news organization, which tend to have archives that can be found easily online. We hoped that by using online versions of these papers, we could capture both what people are reading in print and online. Boykoff (2012) emphasizes that, due to their "geographical circulation, national stature, and influence on public officials, the general population, smaller news outlets, and each other" (p. 253), large print news organizations still

\footnotetext{
${ }^{3}$ Except in Australia, where only one newspaper had searchable online archives.
} 
have an important role to play in the mass media system. We attempted to select the online versions of the highest-circulation print news organizations in each country to examine the nature and subject matter in news coverage seen by the largest numbers of citizens.

In some countries, however, it was not possible to include three news organizations or the highest-circulation organization due to the limited search capacity of some online databases. For example, certain archives could not be sorted by date and others did not have accessible archives reaching back as far as COP21. In these cases, we used articles from fewer newspapers or were unable to include those with the highest circulation. We compared content rather than overall volume of coverage in each country. Therefore, we believe such differences in the number of newspapers did not skew international comparisons. We acknowledge that these newspaper choices do not necessarily represent news coverage to which the entire public of a given country was exposed. In the USA, UK, South Africa, Nigeria, Brazil, Bolivia, and France, we were able to read newspapers in the country's official language (English, Portuguese, Spanish, and French, respectively). In India, China, UAE, Indonesia, and Bangladesh, we used the highest-circulation English language newspapers. ${ }^{4}$

For each of these news organizations, we reviewed ${ }^{5}$ all articles published in the online versions of the newspaper during the 2 weeks of COP21 (November 29th to December 13th, 2015) that were identified using a search of the terms "climate change" and "cop 21 " -2580 separate articles. We did not include opinions and editorials, video or photo journals. We chose to look at articles published only during the 2 weeks of said COP (and not before or after) because the spike in coverage during just those 2 weeks was consistent across all countries. We believe this method provided a substantial comparison between countries and allowed us to focus only on the COP.

To examine which subject areas were covered during the conference, we then categorized each article based on its primary topic. Primary topics were initially determined during the original coding of US coverage based on the most common topics covered in online versions of US print news organizations. ${ }^{6}$ These topics were then revised during coding of the other 12 countries to better reflect international coverage. Articles that discussed multiple subjects were categorized based on the topic discussed most or at the beginning of the article. Most articles fit best into a single category, but the few that discussed multiple topics equally were labeled as fitting into two categories. We double counted 334 articles (13\% of the total articles read). ${ }^{7}$ Our results are presented as the number of articles that fell into each category, reflecting the number of articles of each topic to which a reader might have been exposed.

Primary topics we encountered included:

1. Adaptation: Actions taken to prevent or diminish the adverse effects of climate change.

2. Business and markets: Business reactions, market-based solutions to the climate problem, or the economy.

\footnotetext{
${ }^{4}$ In these countries, we chose English-speaking newspapers that were widely read, although often by urban subpopulations.

${ }^{5}$ We read or skimmed each article from top to bottom to make sure that we had a full grasp of their central topic. ${ }^{6}$ Original US coding was based on previous research (Roberts and Gurwitt 2015) of US newspaper coverage of COP21

${ }^{7}$ For example, an article in The New York Times entitled "Pope, celebrities, activists display shoes ahead of Paris climate change talks" (11/29/2015) was categorized as being about both civil society engagement as well as about a public figure. The number of articles double counted by country are: USA 58, France 36, Australia 7, UK 53, India 40, China 9, UAE 42, Indonesia 8, Bangladesh 9, Brazil 29, Bolivia 23, Nigeria 5, South Africa 15
} 
3. Civil society engagement: Actions and responses of people, celebrities, and NGOs outside the COP, including marches and protests, art exhibits, and more.

4. Denial/skepticism/opposition of climate change action: Doubts cast on the reality of climate change or opposition to climate action.

5. Effects of climate change on natural systems and human populations: Changing climatic conditions and their effects on ecosystems and human populations, e.g., natural disasters, sea level rise, climate refugees, and climate-related health issues.

6. Equity: Issues of climate justice, the vulnerability of developing nations and marginalized communities, and the historical responsibility of industrialized nations to significantly reduce their emissions and support economic growth in developing countries.

7. Finance: Transfer of money from developed to developing nations to help them mitigate or adapt to climate change.

8. Future and solutions: Technology, practices, and innovation that could reduce or mitigate the damage from climate change.

9. General overview: General information about or summary of COP21, such as lists of the key issues at stake or outlining how the process unfolds. These were often brief overviews of multiple issues in the text, but lacking in detail.

10. Land use: Land management, such as agriculture, deforestation, or reforestation.

11. Logistics and security: Planning, organization, or security in place during COP21.

12. Loss and damage: The irreparable losses and damages to communities and ecosystems as a result of anthropogenic climate change, or the subsequent issues of liability and compensation.

13. Mitigation: Goals and strategies for emissions reductions.

14. Negotiation updates: Updates on events and developments from the COP21 negotiations, e.g., draft texts and statements from delegations and UN officials.

15. Other countries: Positions or actions related to climate change of countries other than that in which the newspaper primarily circulates.

16. Public figures: World leaders, politicians, and others in the public eye or with responsibility at the COP (such as celebrities or well-known activists).

17. Religion: Positions of religious groups and leaders, e.g., the Pope's comments on climate change.

18. Transparency: Mechanisms that monitor and uphold responsibility and accountability in the climate regime.

An intercoder reliability test was conducted by calculating Krippendorff's Alpha in SPSS. The test, which used 25 randomly selected articles, yielded an intercoder reliability rate of $86.56 \%$. After coding each article based on its principal topic or topics, we further analyzed any article that focused on a country other than the one in which the news source was based-for instance, an article about Chinese air quality published by Times of India or New York Times coverage of climate policy changes in Denmark. In each of these articles, we categorized the country of focus as being either a developed country, a developing country, or an emerging economy, using the Standard and Poor's (S\&P) Dow Jones Indices Country Classification list (2015, p.20) to define these categories. We used their list of "frontier" economies to define "developing" countries. Finally, we further categorized all articles that fell into the "effects of climate change" category to see whether they focused more on the effects of climate change on natural systems or on human populations. 
We acknowledge several important caveats and limitations to our research. While our chosen news organizations had high readership, our choice to look only at daily print news outlets meant that we were unable to fully capture how certain groups of people in a given country get their news. Many people look to television, radio, social media, or other onlineonly news sources as their primary information source (Newman et al. 2016). Moreover, our methodological decision to analyze only English-language newspapers in certain countries may have presented an incomplete picture of national coverage. Still, the newspapers we chose carry weight in these nations and arguably affect the views of the political and economic elites of these countries, making them relevant for our analysis.

The online archives of our chosen news organizations varied markedly in quality, but we selected newspapers that had fairly comprehensive archives. Because of the nature of online archives, we were unable to differentiate between articles appearing online-only and those appearing in print as well. Finally, we did not distinguish between articles written by a newspaper's own reporters and those taken from wire sources. This is a significant limitation given that Antilla (2005, p. 350) found that wire services were a dominant source of climate news and often propagated the exponential spread of climate skepticism. Regardless, all of the articles we analyzed reflect the news coverage of the Paris negotiations read by online and print consumers of these leading global print media outlets.

\section{Findings}

Topics covered We found that many themes appeared consistently across the 13 countries. The top five overall topics (in order) were as follows: negotiation updates (\#14), effects of climate change (\#5), civil society engagement (\#3), mitigation (\#13), and public figures (\#16) (Appendix 2). Updates had more than twice the number of articles than any other topic, and over 1250 articles (48\% of articles) fell into the top three: updates, effects, and civil society.

Articles about updates primarily consisted of breaking news stories about the text of the agreement and statements from delegations or ministers at the conference. Although these articles helped contextualize COP21 and reveal the priorities of different countries, they frequently lacked deeper analysis. Instead, most articles delivered simplistic overviews of conference proceedings or relied on quotes from well-known world leaders.

Articles that focused on the effects of climate change typically glossed over the negotiations, only mentioning the COP in order to connect a story about climate change impacts to a widely publicized event. For example, article headlines such as "Beijing issues highest level smog alert" (Times of India, 11/30/2015) and "Heavy flooding causes chaos in Chennai" (Gulf News, 12/2/2015) all referenced COP21 briefly. Articles about civil society responses illuminated the large presence of activists and NGOs at COP21, but generally provided little insight into the views or goals of these groups. These articles primarily covered large, wellknown NGOs like the World Wildlife Fund or Greenpeace. ${ }^{8}$

Of the major issues directly mentioned in the negotiating text (such as mitigation, adaptation, transparency, and finance), mitigation was covered most. Climate finance also featured in

\footnotetext{
${ }^{8}$ Article headlines included: "Play heroic role at climate talks, Greenpeace appeals to Modi" (The Hindu, 12/4/ 2015); "Greenpeace: 'Este es el final de la era de las energías fósiles"” (Translation: "This is the end of the era of fossil fuels;" Página Siete, 12/12/2015); “COP21 draft agreement has 'ingredients for an ambitious outcome': WWF" (Global Times, 12/10/2015).
} 
the top ten themes in total coverage (number 10), but appeared less than half as often as mitigation. The other issues that made up the top ten were future and solutions, general overviews, business and markets, and equity.

Shifting coverage Analyzing international news published each day during COP21, we were able to observe changes in the amount of coverage and the themes discussed during the 2 weeks of the conference. Total coverage was higher during the first and last days of the conference than it was during the middle of the event. Stories about activism (protests and marches) and important updates (i.e., breaking news about the conference or the agreement itself) were most prevalent during the first and last days of the conference.

National differences in coverage There were important variations in thematic coverage from country to country. In all but four of the countries (France, Nigeria, UK, and UAE), updates received the highest coverage, and even in these countries, it ranked as the second most-covered topic (Fig. 1). The effects of climate change were among the top five mostreported themes in every country. ${ }^{9}$ Civil society was also among the top five topics in nine countries - and was the most covered topic in France - with articles on marches and protests at the beginning and end of the COP, as well as articles about various art exhibitions, theater exhibits, and other projects related to COP $21 .^{10}$

Among the issues discussed in the text of the Paris Agreement, mitigation appeared among the top five themes in nine countries. By contrast, finance made it into the top five topics in only two countries (Bangladesh and Nigeria), while equity appeared in four countries (Bolivia, Brazil, Nigeria, and South Africa). Adaptation did not appear among the top five topics in any country (and ranked in the top ten only in Bangladesh and India). Although coverage of adaptation was scarce in all of the newspapers we studied, it was least prominently featured in the newspapers from developed countries.

Coverage of equity Equity was discussed differently in various countries. In Bolivia, discussions of equity often appeared in the context of anti-capitalist discourse; for instance, Los Tiempos stated of President Morales that "Evo arremete contra el capitalismo para salvar a la madre Tierra" (Evo battles against capitalism to save Mother Earth). In India, newspapers echoed the Indian delegation's calls for "climate justice." India was one of only two countries that had higher coverage of equity than mitigation (along with the UAE), while Chinese papers also covered equity issues in some detail. Both India and China emphasized discourse related to historic responsibility. ${ }^{11}$

Coverage of public figures The coverage of public figures and world leaders was consistent across all countries that we studied. The media focus tended to focus on the travel plans and statements in response to COP21 of local leaders and a handful of global change-makers, such as President Barack Obama, Prime Minister Narendra Modi, President François Hollande, and

\footnotetext{
${ }^{9}$ Effects of climate change and equity were tied for Brazil's fifth most covered topic with 14 articles each.

${ }^{10}$ Article titles included: "COP21: des milliers participants à la chaîne humaine à Paris" (Translation: "COP21: Thousands of participants in a human chain in Paris"; Le Figaro, 11/29/2015); "Succès de la Marche mondial pour le climat" (Translation: "Success of the world climate march"; Le Monde, 11/30/2015).

${ }^{11}$ For instance, "India wants right to carbon space to uplift millions from poverty" (Hindustan Times, 11/30/ 2015) and "China reaffirms the key principle of 'common but differentiated responsibility"' (China Daily, 12/1/ 2015).
} 


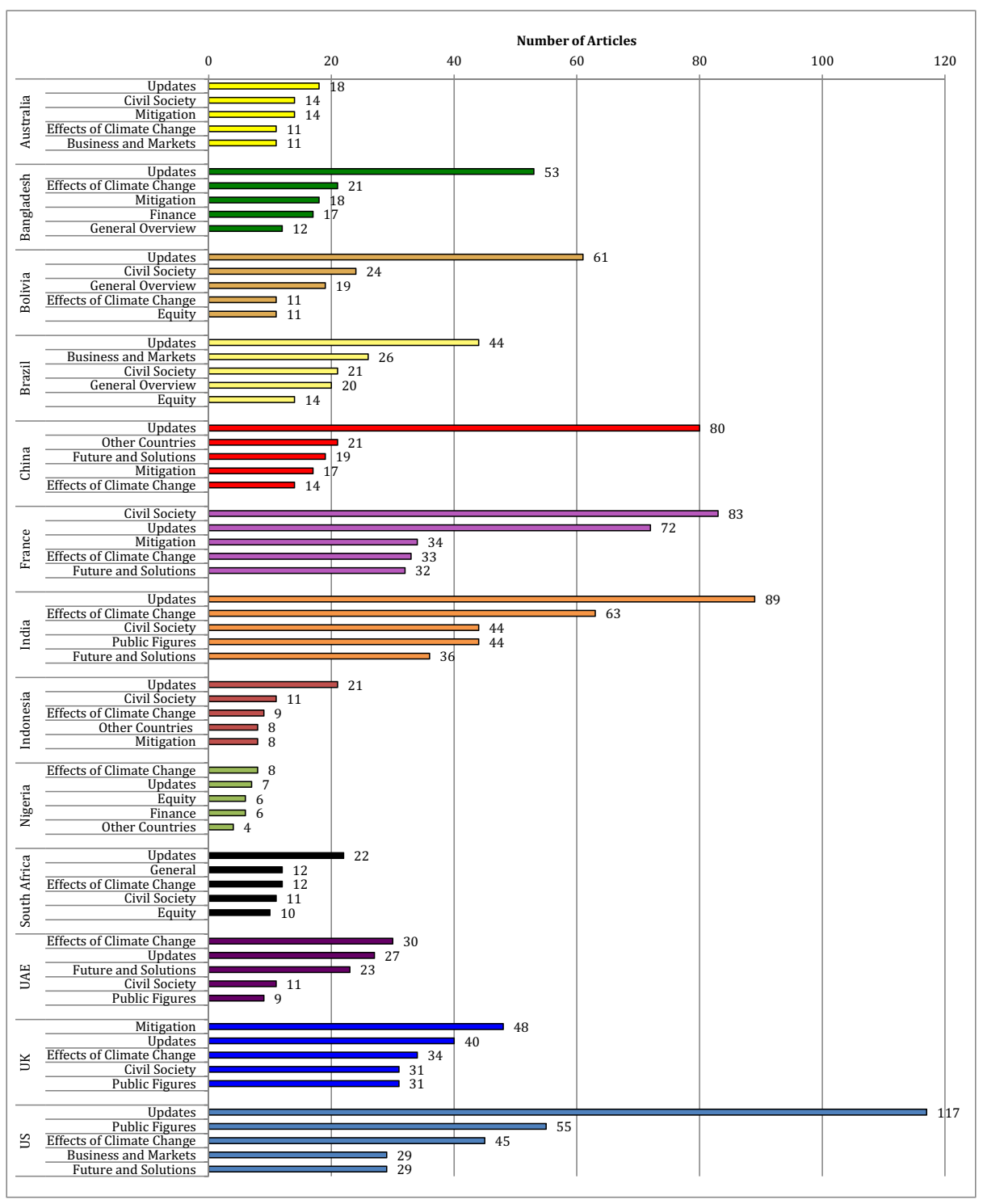

Fig. 1 Top five themes in coverage by country

Secretary General Ban Ki-Moon. Examples included the following: "Obama Hails Historic Agreement on Climate Change" (Wall Street Journal, 12/13/2015); "For UN's Ban, Climate Deal is Personal Victory After Setbacks" (New York Times, 12/13/2015); and "Narendra Modi says climate justice won in Paris accord" (Khaleej Times, 12/13/2015). All of these major players represent developed or large emerging economies. Leaders from developing countries rarely appeared in the newspaper coverage in other nations.

National contexts The press in some countries focused on topics that were specific to their national contexts. French papers carried the most coverage of logistics and security 
surrounding COP21, which was unsurprising given that the country was still reeling from terrorist attacks that had occurred 2 weeks prior. In all three Brazilian newspapers we analyzed, there was significant coverage of land use and deforestation, corresponding with the history of Brazil's rainforests. In line with Bolivia's open opposition to the Cancun Agreement arising from COP 16, Bolivian newspapers took a critical stance on the COP proceedings. ${ }^{12}$

Finally, the USA was the only country in which climate opposition made it into the ten mostcovered topics. News organizations reported on Republican presidential candidates criticizing action on climate change or that party's opposition to Obama's ambition at COP21 and the Clean Power Plan, with articles such as "Obama Optimism Over Climate Pact Tempered by GOP Opposition" (New York Times, 12/13/2015) and "House Votes to Block EPA PowerPlant Rules" (Wall Street Journal, 12/1/2015). This falls in line with previous research highlighting the unusual climate of skepticism in the American media due to their emphasis on journalistic balance and other factors (Antilla 2010; Boykoff and Boykoff 2004).

Coverage of developed countries, emerging economies, and developing countries We also compared the relative coverage of developing countries, emerging economies, and developed countries. Of articles that focused on another country, there was more coverage of either developed countries or emerging economies. In particular, we found many articles that examined the US elections, air pollution in Beijing, and the Chennai floods in newspapers not in those countries. The issues of the most vulnerable developing countries were reported much less frequently (Fig. 2). Nigerian news organizations had the most coverage of the developing world, followed by those in Bolivia. Brazil and South Africa, on the other hand, carried no stories about developing countries.

France had the most balanced coverage of developed countries, emerging economies, and developing countries, with extensive coverage of African nations specifically. ${ }^{13}$ In China, coverage was likewise well divided between these three types of countries, also with great focus on developing nations in Africa. This focus likely arose from President Xi Jinping's tour of Africa, which coincided with COP21; many articles featured in the Chinese newspapers consisted of hard news stories related to his trip, with only tangential references to the COP. ${ }^{14}$ Newspapers in the USA, the UK, and India had particularly unbalanced coverage, skewed mainly towards coverage of developed nations.

Consideration of climate change impacts on human populations Finally, we examined how coverage of the effects of climate change differed between natural systems and human populations (Fig. 3). While media in most countries featured extensive coverage of effects on natural systems (for instance, rising temperatures or sea levels), there was less about how those environmental changes will affect human populations (for example, by decreasing the viability of certain crops, or forcing migration from retreating shorelines). Media organizations in only two countries, Nigeria and Brazil, discussed the impacts of climate change on human populations more often than they discussed the effects of climate change on natural systems.

\footnotetext{
${ }^{12}$ With headlines such as "No serán los políticos quienes resuelvan el cambio climático" (Translation: "It will not be politicians who solve climate change;" Página Siete, 12/10/2015).

${ }^{13}$ Examples of article headlines include: "Un plan pour relever le défi climatique en Afrique" (Translation: "A plan for lifting the climate challenge in Africa;" Le Monde, 12/2/2015); and "Pauvreté et transitions énergétique: les deux défis de l'Afrique du Sud" (Translation: "Poverty and energy transitions: the two challenges for South Africa;" Le Monde, 12/8/2015).

${ }^{14}$ For example, "President Xi leaves for visit to Paris, Africa" (China Daily, 11/29/2015); and "China plays responsible role in fighting climate change, promoting African development" (Global Times, 12/6/2015).
} 


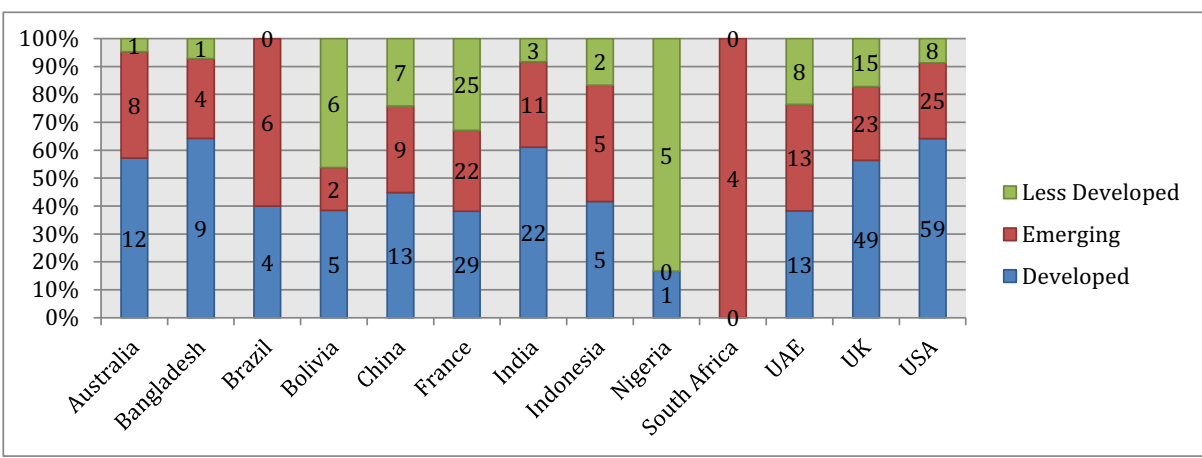

Fig. 2 Relative coverage of less developed, emerging and developed countries

\section{Discussion}

COP21 generated substantial media coverage around the world, but much of this coverage was based on a limited range of issues and did not fully reflect the depth, range, and complexities of the debates within and around the conference. The coverage generally adhered to several journalistic norms described by Boykoff and Boykoff $(2004,2007),{ }^{15}$ particularly novelty and dramatization. Stories were simplified and sensationalized, with the coverage of the conference often reduced to a few speeches and events. The top three topics in total coverage - updates, effects of climate change, and civil society responses — often lacked deep analysis.

The overall coverage also centered around the concerns, priorities, and actions of developed countries. For instance, although the conference was framed by many world leaders and activists as a summit primarily about emissions reductions, there were other major issues discussed that were arguably of greater significance to developing countries (adaptation, finance and loss, and damage). However, even the coverage in developing countries like Bangladesh and Nigeria focused on mitigation rather than domestic priorities like adaptation. Adaptation is a central tenet of the Paris Agreement and its intricacies were hotly debated during COP21, yet we found fewer than ten articles focusing on adaptation in over 2500 stories. The concept of loss and damage also produced a large outcry from activists and world leaders at the conference but was largely absent from global media coverage.

In addition, we noticed that immediately-visible effects of climate change were emphasized while long-term challenges discussed during the conference (such as climate refugees and the health effects of climate change) were rarely mentioned. This emphasis on the effects of climate change on natural systems rather than on human populations reflects a priority of the developed world, where climate-related risks do not compound existing social injustice as much as in the developing world (Kasperson and Kasperson 2001). While this may have helped contextualize the conference in terms of larger world events and made it more relevant to the public, it likely resulted in a lost opportunity to explore the many facets of climate change. We saw few stories illustrating concepts like hunger crises due to climate impacts or changing migration patterns, which could have been used to highlight the more complex debates within the COP about equity.

The discussion of equity issues in particular highlighted the priorities of developed countries. Tensions at UN climate negotiations consistently arise from the notion that countries that have

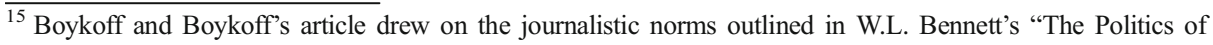
Illusion" (1983). 


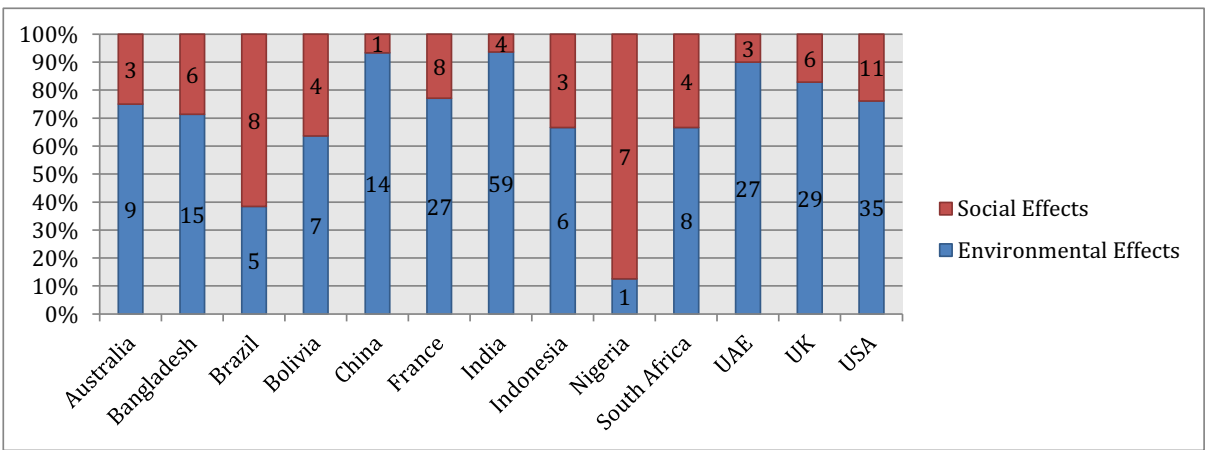

Fig. 3 Relative coverage of environmental and social effects of climate change

contributed more to climate change and benefited from carbon-intensive economic development should be held to more stringent emissions regulation and provide aid to poor, climate vulnerable countries (Roberts and Parks 2006; Ciplet et al. 2015). Yet international media coverage of equity was scarce, vague, and limited in scope. Debates over indigenous rights and gender equity in the Paris Agreement were largely missing from media coverage, particularly in developed countries. Instead, when equity was mentioned, it typically denoted discussion of historic and future responsibility for emissions reductions in different countries.

Boykoff and Boykoff (2007) also identify journalists' tendency to adhere to authority-order bias, a second-order journalistic norm wherein media sources primarily include the opinions of leaders and authority figures. We noted this tendency in media coverage of COP21: Journalists often emphasized the activities and relationships of world leaders at the conference. While these leaders played a major role in the negotiations, they are nonetheless only one part of a greater framework of stakeholders and interests involved in the process, and most of the actual negotiations are of course done by staff. The emphasis on world leaders and their celebratory rhetoric resulted in a horserace view of the conference and its outcome. Journalists seldom provided measured coverage of both the negative and positive aspects of the final text, what might need to happen in the future for the agreement to be effective, how ratchet mechanisms ${ }^{16}$ would be implemented in coming years, or how the agreement might affect or be affected by future COPs.

Large-scale international events like the COPs - which attract public attention from all around the world - are valuable opportunities for the media to inform readers of climate change and climate policy. Similar research should be conducted to see how the media covers future COPs and other large climate events, and how the breakdown of subject areas discussed in news stories adapts over time. Further research could also compare the topics most covered in the media with those that were most often discussed in negotiations or in the final text, as well as analyze the voices quoted in print news articles around the world. Both of these analyses would further highlight the topics or types of people absent from prominent media coverage - the areas of importance to negotiations or perspectives that are often overlooked by the rest of the world. Media research (at COPs or of climate change in general) could also compare the degree of focus on the effects of climate change on natural systems versus human populations. And finally, further research could investigate the disparity in coverage focusing on developed countries, emerging economies, and developing countries to better

\footnotetext{
${ }^{16}$ The "ratchet" mechanism is the underlying process of increasing mitigation commitments in Intended Nationally Determined Contributions (INDCs) every 5 years, with each commitment more ambitious than the last.
} 
understand how inequities in negotiations translate to inequities in policy and public awareness. The media is a vital link between politicians, experts, and citizens, and understanding which topics and voices are missing from coverage is crucial.

Acknowledgements We would like to thank Professor Timmons Roberts for presenting us with the opportunity to explore global climate politics not only inside the confines of the classroom but also at COP21; this experience was invaluable and irreplaceable. We would also like to thank Brown University, and specifically the Institute at Brown for Environment and Society (IBES) for funding our research. Finally, we would like to thank our three anonymous reviewers for their valuable suggestions.

\section{Appendix 1}

Table 1 Number of articles per country and newspaper

\begin{tabular}{|c|c|c|c|}
\hline Country & $\begin{array}{l}\text { Total number of } \\
\text { articles }\end{array}$ & Newspapers & $\begin{array}{l}\text { Number of articles by } \\
\text { newspaper }\end{array}$ \\
\hline Australia & 112 & $\begin{array}{l}\text { The Sydney Morning } \\
\text { Herald }\end{array}$ & 112 \\
\hline \multirow[t]{3}{*}{ Bangladesh } & \multirow[t]{3}{*}{161} & Dhaka Tribune & 64 \\
\hline & & Financial Express & 61 \\
\hline & & The Daily Star & 36 \\
\hline \multirow[t]{3}{*}{ Brazil (Portuguese) } & \multirow[t]{3}{*}{195} & Estado de S. Paulo & 65 \\
\hline & & Folha de S. Paulo & 70 \\
\hline & & Valor Econômico & 60 \\
\hline \multirow[t]{3}{*}{ Bolivia (Spanish) } & \multirow[t]{3}{*}{159} & Página Siete & 86 \\
\hline & & El Deber & 26 \\
\hline & & Los Tiempos & 47 \\
\hline \multirow[t]{3}{*}{ China } & \multirow[t]{3}{*}{195} & China Daily & 80 \\
\hline & & Shanghai Daily & 21 \\
\hline & & Global Times & 94 \\
\hline \multirow[t]{2}{*}{ France (French) } & \multirow[t]{2}{*}{383} & Le Figaro & 177 \\
\hline & & Le Monde & 206 \\
\hline \multirow[t]{3}{*}{ India } & \multirow[t]{3}{*}{384} & Times of India & 168 \\
\hline & & The Hindu & 142 \\
\hline & & Hindustan Times & 74 \\
\hline \multirow[t]{2}{*}{ Indonesia } & \multirow[t]{2}{*}{90} & Jakarta Globe & 47 \\
\hline & & Jakarta Post & 43 \\
\hline \multirow[t]{3}{*}{ Nigeria } & \multirow[t]{3}{*}{38} & The Guardian & 10 \\
\hline & & Vanguard & 14 \\
\hline & & Daily Trust & 14 \\
\hline \multirow[t]{3}{*}{ South Africa } & \multirow[t]{3}{*}{100} & The Sowetan & 11 \\
\hline & & Times Live & 48 \\
\hline & & IOL & 40 \\
\hline \multirow[t]{3}{*}{ United Arab Emirates } & \multirow[t]{3}{*}{123} & Gulf News & 70 \\
\hline & & Khaleej Times & 33 \\
\hline & & The National & 20 \\
\hline \multirow[t]{3}{*}{ United Kingdom } & \multirow[t]{3}{*}{265} & The Guardian & 186 \\
\hline & & The Telegraph & 42 \\
\hline & & The Times & 37 \\
\hline \multirow{3}{*}{$\begin{array}{l}\text { United States of } \\
\text { America }\end{array}$} & \multirow[t]{3}{*}{375} & Los Angeles Times & 105 \\
\hline & & New York Times & 238 \\
\hline & & Wall Street Journal & 32 \\
\hline
\end{tabular}




\section{Appendix 2}

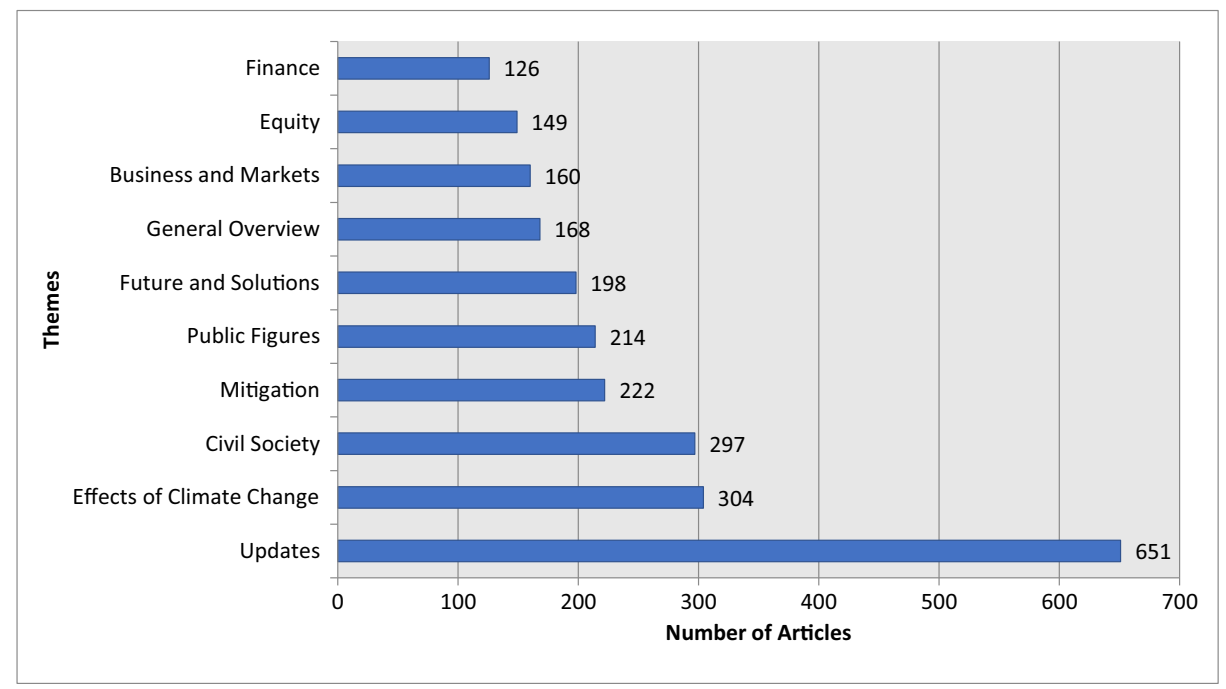

Fig. 4 Top ten themes in total coverage

Open Access This article is distributed under the terms of the Creative Commons Attribution 4.0 International License (http://creativecommons.org/licenses/by/4.0/), which permits unrestricted use, distribution, and reproduction in any medium, provided you give appropriate credit to the original author(s) and the source, provide a link to the Creative Commons license, and indicate if changes were made.

\section{References}

Antilla L (2005) Climate of Scepticism: US newspaper coverage of the science of climate change. Glob Environ Chang 15(4):338-352

Antilla L (2010) Self-censorship \& science: a geographical review of media coverage of climate tipping points.

Public Underst Sci 19(2):240-256

Bennett WL (1983) News: the politics of illusion. Longman, New York

Billett S (2010) Dividing climate change: global warming in the Indian mass media. Clim Chang 99:1-2

Boykoff MT (2008a) Lost in translation? United States television news coverage of anthropogenic climate change, 1995-2004. Clim Chang 86(1):1-17

Boykoff MT (2008b) The cultural politics of climate change discourse in UK tabloids. Polit Geogr 27(5):549-569

Boykoff MT (2010) Indian media representations of climate change in a threatened journalistic ecosystem. Clim Chang 99(1):17-25

Boykoff JM (2012) US media coverage of the Cancun climate change conference. PS: Polit Sci Polit 45(2):251258

Boykoff MT, Boykoff JM (2004) Balance as bias: global warming and the US prestige press. Glob Environ Chang 14(2):125-136

Boykoff MT, Boykoff JM (2007) Climate change and journalistic norms: a case-study of US mass-media coverage. Geoforum 38(6):1190-1204

Boykoff MT, Rajan SR (2007) Signals and noise. Mass media coverage of climate change in the USA and the UK. EMBO Rep 8(3):207-211

Brüggemann M, Engesser S (2017) Beyond false balance: how interpretive journalism shapes media coverage of climate change. Glob Environ Chang 42:58-67 
Brulle RJ, Carmichael J, Jenkins C (2012) Shifting public opinion on climate change: an empirical assessment of factors influencing concern over climate change in the U.S., 2002-2010. Clim Chang 114(2):169-188

Carvalho A, Burgess J (2005) Cultural circuits of climate change in UK broadsheet newspapers, 1985-2003. Risk Anal 25(6):1457-1469

Ciplet D, Roberts JT, Khan MR (2015) Power in a warming world: the new global politics of climate change and the remaking of environmental inequality. MIT Press, Cambridge

Doulton H, Brown K (2009) Ten years to prevent catastrophe? Discourses of climate change and international development in the UK press. Glob Environ Chang 19:191-202

Downs A (1972) Up and down with ecology-the "issue-attention cycle". Public Interest 28:38-50

Einsiedel E (1992) Framing science \& technology in the Canadian press. Public Underst Sci 1(1):89-101

Fioravanti C, Painter J (2011) Country Study: Brazil. IN: Painter, J. Poles apart: the international reporting of climate skepticism. Reuters Institute for the Study of Journalism, Oxford

Gans H (2004) Deciding what's news: a study of CBS Evening News, NBC Nightly News, Newsweek \& Time. Northwestern University Press, Evanston

Gavin NT, Marshall T (2011) Mediated climate change in Britain: scepticism on the web and on television around Copenhagen. Glob Environ Chang Hum Policy Dimens 21(3):1035-1044

Gelbspan R (2004) Boiling point: how politicians, big oil \& coal, journalists, \& activists are fueling the climate crisis - and what we can do to avert disaster. Basic Books, New York

Henderson-Sellers A (1998) Climate whispers: media communication about climate change. Clim Chang 40: $421-456$

Kasperson RE, Kasperson JX (2001) Climate change, vulnerability and social justice. Stockholm Environment Institute. http://stc.umsl.edu/essj/unit4/climate\%20change\%20risk.pdf

Kunelius R, Eide E (2012) Moment of hope, mode of realism: on the dynamics of a transnational journalistic field during UN climate change summits. J Int Commun 6:266-285

Liu X, Lindquist E, Vedlitz A (2011) Explaining media and congressional attention to global climate change, 1969-2005: an empirical test of agenda-setting theory. Polit Res Q 64(2):405-419

Luck J, Wozniak A, Wessler H (2016) Networks of coproduction: how journalists and environmental NGOs create common interpretations of the UN climate change conferences. Int J Press Polit 21(1):25-47

Luedecke G, McAllister L, Nacu-Schmidt A, Andrews K, Boykoff M, Daly M, Gifford L (2016) World Newspaper Coverage of Climate Change or Global Warming, 2004-2016. Center for Science and Technology Policy Research, Cooperative Institute for Research in Environmental Sciences, University of Colorado, Web

McComas K, Shanahan J (1999) Telling stories about global climate change: measuring the impact of narratives on issue cycles. Commun Res 26(1):30-57

McManus PA (2000) Beyond Kyoto? Media representations of an environmental issue. Aust Geogr Stud 38(3): 306-319

Nelkin D (1995) Selling science: how the press covers science \& technology, revised edn. W.H. Freeman \& Co., New York

Newman N, Fletcher R, Levy DA, Nielsen RK (2016) Reuters Institute Digital News Report 2016 (Rep.). Reuters Institute For the Study of Journalism

Nissani M (1999) Media coverage of the greenhouse effect. Popul Environ 21(1):27-43

O’Neill S, Williams HT, Kurz T, Wiersma B, Boykoff M (2015) Dominant frames in legacy and social media coverage of the IPCC Fifth Assessment Report. Nat Clim Chang 5(4):380-385

Painter J (2010) Summoned by science: reporting climate change at Copenhagen and beyond. Reuters Institute for the Study of Journalism, Oxford

Roberts JT, Gurwitt S (2015) The Paris climate talks according to U.S. print media: plenty of heat, but not so much light. Brookings Institution: PlanetPolicy Blog. https://www.brookings.edu/blog/planetpolicy/2015/12 /18/the-paris-climate-talks-according-to-u-s-print-media-plenty-of-heat-but-not-so-much-light/

Roberts JT, Parks B (2006) A climate of injustice: global inequality, North-South politics, and climate policy. MIT Press, Cambridge

Sampei Y, Aoyagi-Usui M (2009) Mass-media coverage, its influence on public awareness of climate-change issues, and implications for Japan's national campaign to reduce greenhouse gas emissions. Glob Environ Chang 19(2):203-212

Schmidt A, Ivanova A, Schäfer MS (2013) Media attention for climate change around the world: a comparative analysis of newspaper coverage in 27 countries. Glob Environ Chang 23(5):1233-1248

Shanahan M (2009) Time to adapt? Media coverage of climate change in nonindustrialised countries. In: Boyce T, Lewis J (eds) Climate change and the media. Lang, London, pp 145-157

Standard \& Poor's (2015) Dow Jones Indices Country Classification review (Rep.)

Sundblad E, Biel A, Gärling T (2009) Knowledge and confidence in knowledge about climate change among experts, journalists, politicians, and laypersons. Environ Behav 41(2):281-302 
Tagbo E (2010) Media coverage of climate change in Africa: a case study of Nigeria and South Africa. Reuters Institute for the Study of Journalism. http://reutersinstitute.politics.ox.ac.uk/publication/media-coverageclimate-change-africa

Tolan S (2007) Coverage of climate change in the Chinese Media. Human Development Report 2007/8. http:/hdr.undp.org/en/reports/global/hdr2007-2008/papers/tolan_sandy.pdf

Trumbo C (1996) Constructing climate change: claims \& frames in US news coverage of an environmental issue. Public Underst Sci 5:269-283

Wilson K (2000a) Communicating climate change through the media: predictions, politics \& perceptions of risk. In: Allan S, Adam B, Carter C (eds) Environmental risks \& the media. Routledge, London, pp 201-217

Wilson K (2000b) Drought, debate and uncertainty: measuring reporters' knowledge \& ignorance about climate change. Public Underst Sci 9:1-13

Wozniak A, Wessler H, Luck J (2016) Who prevails in the visual framing contest about the United Nations Climate Change Conferences? Journalism Studies. doi:10.1080/1461670X.2015.1131129

Young N, Dugas E (2011) Representations of climate change in Canadian national print media: the canalization of global warming. Can Rev Sociol/Revue canadienne de sociologie 48(1):1-22

Zehr S (2000) Public representations of scientific uncertainty about global climate change. Public Underst Sci 9: $85-103$ 